\title{
THE ROLE OF LOCAL UNIVERSITIES IN THE DIFFUSION OF SOCIAL INNOVATIONS: THE CASE OF THE MUNICIPAL DISTRICT OF QUITO
}

\author{
Klaus Gierhake \\ Research associate Zentrum für internationale \\ Entwicklungs- und Umweltforschung \\ University of Giessen (Germany) \\ gierhake@gmail.com
}

\author{
Carlos Maria Fernandez Jardon \\ Department of Applied Economics-ECOBAS \\ University of Vigo, Vigo (Spain) \\ National Research University Higher School of \\ Economics, Perm (Russia) \\ cjardon@uvigo.es
}

\author{
Reception date: 04/08/2021 - Approval date: 05/06/2021 \\ DOI: https://doi.org/10.36995/j.visiondefuturo.2021.26.01.004.en
}

\section{ABSTRACT}

Local knowledge helps generate social innovations. Universities, which are part of the territorial innovation system, are important in creating innovations, but their role in diffusing social innovations is less well known. The social policies established in Ecuador have given rise to different social innovations. In particular, the metropolitan district of Quito, based on the metropolitan development plan from 2012 to 2022, has generated a process of social innovations of great interest. Local universities usually participate in the training process of the agents involved in the development of social innovation. In a complementary way, local universities can facilitate cooperation between these agents. Both are essential elements in the diffusion of innovation. This paper analyzes the importance of collaboration with universities to disseminate social innovations in the Metropolitan District of Quito, using a series of interviews. The results indicate that the lack of collaboration with the universities and the limited knowledge that exists in them hampered the practical development of the plan and its effectiveness.

KEY WORDS: Territory; Social innovation; Metropolitan District of Quito; Universities collaboration; Social innovation.

\section{INTRODUCTION}

The political transformations that have occurred in recent years in different Latin American countries (Battaglino, 2015) marked a change in the orientation of political objectives. In Ecuador, in particular, a new constitution more oriented towards sustainable development was established (Manosalvas, 2014), which is part of the global action plan that the United Nations approved at the 1992 Rio conference for countries' economic policies (UN, 1992). Sustainable development in territories is often associated with a continuous innovative

\footnotetext{
"Visión de Futuro" Año 19, Volumen No 26 N 1, Enero - Junio 2022 - Pág 149 - 168 URL de la Revista: http://visiondefuturo.fce.unam.edu.ar/index.php/visiondefuturo/index URL del Documento: https://visiondefuturo.fce.unam.edu.ar/index.php/visiondefuturo/issue/view/22 ISSN 1668 - 8708 - Versión en Línea E-mail: revistacientifica@fce.unam.edu.ar 
process (KetelhöhnandOgliastri, 2013), the result of the existence of creative environments (Butzin, 2000), which enable the generation of wealth and employment. This is the essence of learning regions.

Territories that learn are better prepared to face the challenges of the future, as is the case with the search for strategies to adapt to climate change and different forms of sustainable use of the territory (Ogdenandlnnes, 2009). Sustainable development requires a concern to improve the region economically, socially, and environmentally by combining the three aspects in its development strategies (Placet et al., 2005). These strategies are conditioned by resource constraints and different environmental risks that especially affect developing countries (Williamson et al., 2012). Consequently, in these countries, there is a special interest in seeking social innovations that mitigate the effects of these potential changes and their limited resources. Social innovations are usually associated with the territory since it integrates economic, social and environmental aspects (LiandToppinen, 2011). There are different studies at the territorial level, mainly oriented to the regional or national level (BernardinoandSantos, 2017; Conejero Paz and Redondo Lebrero, 2016; García-Flores and Martos, 2019; Jardon and Gierhake, 2017). Less common are works oriented to the municipal level (Bernardino and Santos, 2017; Wolfe, 2009). However, social actions developed at a territorial level close to the people, as is the case of municipalities, usually have a more permanent and effective effect, since the participating agents feel more committed (FEMP, 2011). Social innovation in small territories is usually based on the local innovation system, since many of the externalities generated by the system positively affect economic and social agents. The interaction between business innovations and local innovation systems has been analyzed (Dameri and Ricciardi, 2015), but the relationship of that system with social innovations needs further formalization (Bernardino and Santos, 2017; García-Flores and Martos, 2019; Oeij et al., 2019).

Within these systems, previous work has analyzed the importance of collaboration with universities and research centers to generate innovations (Mingxing et al., 2020) and, more particularly, how universities help to create social innovations (Conejero Paz and Redondo Lebrero, 2016; García-Flores and Martos, 2019). However, the contribution of local universities to the diffusion of innovations in the territory needs further analysis.

The concept of social innovation has been analyzed in different works (Conejero Paz and Redondo Lebrero, 2016; García-Flores and Martos, 2019; Oeij et al., 2019), although the definitions are very diverse and there are different approaches and characterizations (GarcíaFlores and Martos, 2019). In general, most papers agree on two characteristic aspects of social innovation: the novelty, i.e., a new idea that changes processes, products, organization, etc., 
common with all innovations (García-Flores and Martos, 2019); and the social orientation (Conejero Paz and Redondo Lebrero, 2016; Oeij et al., 2019), which essentially differentiates it from other types of innovation. This second aspect is the most difficult to analyze since there is no consensus on what is a social good, except in some particular cases. That limits to know where a social innovation appears and where it does not.

One of the characteristics usually required of innovation is that it should be sustainable, i.e., that it should satisfactorily meet its objectives from an economic, social, and environmental view (Placet et al., 2005). Many of the innovations proposed in different works do not assume economic sustainability and, in many cases, do not analyze environmental aspects (Wethinq, 2016), so they should not be considered social innovations per se. Consequently, studies on particular aspects of social innovation are highly conditioned by the definition of social innovation (Conejero Paz and Redondo Lebrero, 2016; Oeij et al., 2019; Wolfe, 2009). In particular, this is the case with studies on the factors that favor or limit social innovation.

Within the broader block of factors that limit social innovation, there are two key aspects: the training of the participating agents and the existing cooperation between the agents involved in the development of innovation (García-Flores and Martos, 2019). These two aspects encompass many of the topics pointed out in previous studies (Bernardino and Santos, 2017; García-Flores and Martos, 2019; Jardon and Gierhake, 2017; Wolfe, 2009). In the interplay of these two aspects is the collaboration with local universities.

Local knowledge is formed by the set of knowledge, traditions, and behaviors that have helped the inhabitants of the territory to adapt to environmental changes that occurred during its history (Jardon and Gierhake, 2017). It is therefore a set of intangible assets associated with the territory. These adaptations have helped them to maintain a balance in their development and have allowed the territory to have certain sustainability.

Local knowledge is part of regional intellectual capital (Jardon and Gierhake, 2017). Intellectual capital has been analyzed in countries and regions (Seleim and Bontis, 2013), although there are hardly any studies at the municipal level, possibly because the available information does not capture much of the aspects associated with this concept. Previous work has studied local knowledge as a factor of social innovation (Jardon and Gierhake, 2017). However, the mechanism by which local knowledge acts to diffuse social innovation has not been sufficiently analyzed. A part of local knowledge, especially, explicit knowledge (Brökel, 2016), is or should be, found in the universities of the territory. Since local knowledge helps to diffuse innovation, this is expected to occur in territories where social innovations are produced. However, the particularities of social innovation, for example, its character as a

\footnotetext{
“Visión de Futuro" Año 19, Volumen No 26 N 1, Enero - Junio 2022 - Pág 149 - 168 URL de la Revista: http://visiondefuturo.fce.unam.edu.ar/index.php/visiondefuturo/index

URL del Documento: https://visiondefuturo.fce.unam.edu.ar/index.php/visiondefuturo/issue/view/22

ISSN 1668 - 8708 - Versión en Línea

E-mail: revistacientifica@fce.unam.edu.ar
} 
collective good (Eizaguirre Anglada, 2017) and the cultural aspects associated with its success (Mendes et al., 2012) hinder the diffusion of innovation, which may cause it to fail.

The thesis we present in this paper is that the existence of local knowledge in a territory fosters social innovation, but if there is no fluid collaboration with local universities, the impact of social innovation in the territory is very limited. To test this thesis, we follow a process of social innovation development, similar to the scheme of entrepreneurial innovations (Oeij et al., 2019) adapted to the situation of small territories. Then, it is pointed out how local knowledge affects the diffusion of social innovations, highlighting the importance of collaboration with local universities to make this process successful. The empirical verification is carried out by studying the case of the Municipality of the Metropolitan District of Quito (MDMQ) since the actions developed through the Quito Metropolitan Development Plan 20122022 (MDMQ, 2012c) and its instruments (MDMQ, 2012b, 2012c, 2012a) show an example of social innovation at the municipal level, in which elements of the local innovation system are involved, in such a way that they facilitate the understanding of the scope of social innovations and their consequences at the political, economic and social levels.

The paper combines a two-pronged approach. On the one hand, it uses a sectoral approach that analyzes the innovation process from a more economic point of view, considering the different elements that make up regional innovation systems (Lau and Lo, 2015). On the other hand, it uses a holistic territorial approach, from a more geographical point of view, considering aspects of the geography of innovation (Jardon and Gierhake, 2020).

The outline of the paper continues as follows: First, the theoretical framework of the barriers to the diffusion of social innovation and its connection with local knowledge is studied, analyzing these concepts and their relationship in the territory. Next, the methodology is presented. Then, the case of the DMQ is analyzed from the previously exposed theories, with the idea of showing the effects that local knowledge has on the barriers to social innovation. Finally, the conclusions are presented.

\section{DEVELOPMENT}

\section{Social innovations}

The concept of social innovation presents multiple meanings and approaches that make its formalization difficult (Conejero Paz and Redondo Lebrero, 2016; García-Flores and Martos, 2019; Oeij et al., 2019; Wolfe, 2009). In general, the definitions use two key elements to define this concept associated with the idea of novelty and the idea of social improvement. The idea of novelty is implicit in the concept of innovation itself, i.e., "the conception and

\footnotetext{
"Visión de Futuro" Año 19, Volumen N²6 N 1, Enero - Junio 2022 - Pág 149 - 168 URL de la Revista: http://visiondefuturo.fce.unam.edu.ar/index.php/visiondefuturo/index

URL del Documento: https://visiondefuturo.fce.unam.edu.ar/index.php/visiondefuturo/issue/view/22 
implementation of significant changes ... to improve results" (OECD, 2005, p.44). The idea of social improvement is more complex and difficult to analyze since it may be conditioned by ideologies and have associated political and social implications that are not shared by society as a whole and, in many cases, not even by a majority. This makes it difficult to use this concept in practice. Authors tend to alleviate this difficulty by using generic concepts. For example, Rodríguez Herrera and Alvarado Ugarte (2008) suggest that social innovations must include some kind of social impact, since they must benefit a significant group of people, contributing to poverty reduction or a better quality of life for groups at social risk and, at the same time, they must be environmental. These authors also include its novelty character, when they suggest that, in addition, it must have the capacity to transform some aspect of society. According to the conception we propose that social innovation must also produce an economic improvement, another aspect of sustainable development (Placet et al., 2005). Social innovation must be able to spread to other situations and places because it should be able to be reproduced in another place or situation and/or on a larger scale. Social innovations tend by their essence to diffuse and expand (Rodríguez Herrera and Alvarado Ugarte, 2008). Social innovations do not seek to generate advantages over competitors and do not have to be protected by patents (Morales Gutiérrez, 2009), therefore, they can be considered open innovations. This means that social innovations normally have a certain element of intangibility and, at the same time, are intimately connected with sustainable development.

Social innovation has territorial repercussions, given that both its birth and its development are supported by territorial resources (Garcia-Flores and Martos, 2019). Within a territory, all innovations show a dynamic diffusion process (Jardon and Gierhake, 2018). In such processes, the main actors, the communication channels, the barriers, and the time needed for an innovation to move in the territorial space are usually distinguished. Those aspects are going to be analyzed in MDMQ so that we can extract experiences that will allow to elaborate a theoretical conceptualization that will facilitate future social innovations.

García-Flores and Martos(2019), based on an empirical study, classify the factors of innovation irruption in five aspects: cultural and social factors of the population, political and institutional support, knowledge and facilitating mechanisms, spatial components, and entities and mechanisms that determine the business and social productive structure. Oganisjana et al.(2015) analyze social innovation factors by systematizing them as internal and external factors about an individual or a group of individuals. In particular, they focus on barriers. The main internal barriers are those associated with individuals, such as mentality, resistance to change, or underdeveloped competencies (Koch and Hauknes, 2005), among other elements. External barriers are conditioned to more complex challenges such as excessive bureaucratic

\footnotetext{
“Visión de Futuro" Año 19, Volumen No 26 N 1, Enero - Junio 2022 - Pág 149 - 168 URL de la Revista: http://visiondefuturo.fce.unam.edu.ar/index.php/visiondefuturo/index

URL del Documento: https://visiondefuturo.fce.unam.edu.ar/index.php/visiondefuturo/issue/view/22

ISSN 1668 - 8708 - Versión en Línea

E-mail: revistacientifica@fce.unam.edu.ar
} 
rules, administrative and legal framework delivery pressures (Clark et al., 2008), lack of capacity for organizational learning at all levels (Mendes et al., 2012), and insufficient funding (Koch and Hauknes, 2005; Mendes et al., 2012).

Oeij et al.(2019) approach social innovation as a process by pointing out the key elements in each phase. In the initial phase, the main thing is the commitment of stakeholders; in the planning phase, financial and institutional support; in the development phase, there are the agreements between the different participants and the capacity to overcome possible setbacks that may arise. In this phase, consensus, leadership capacity, external relations, and the existence of infrastructures that favor the process are fundamental. In the implementation and dissemination phase, the social value of the innovation, local adaptation, and the possibilities of extension to other territories is key. Collaboration with local universities appears as a factor in social innovation as part of the local innovation system (García-Flores and Martos, 2019; Mendes et al., 2012; Oeij et al., 2019), but they do not appear as a key factor in the diffusion of social innovation.

\section{Actors in the process of social innovations}

Oeij et al.(2019) propose a model for the generation of social innovations similar to the model of business innovations. This model presents three periods. Each of them includes different phases and participating actors. The first period is the initiation period, which refers to the creation of the innovation; the second is the development period, which corresponds to the process of elaboration and structuring of the innovation; and the last is the implementation and termination process, which includes diffusion after the adoption of the innovation. This is the phase of greatest interest in this paper.

The diffusion of social innovations follows a process similar to business innovations (Oeij et al., 2019), although it presents differences, especially in the importance that the actors involved in this innovation have in its development (Gierhake and Jardon, 2017). Traditional models of business innovation point out that the actors of innovation are companies, as the main actor, the public sector, and research centers (Abbas et al., 2019). These actors can also intervene in social innovation, but this includes other actors of greater importance. Gierhake (2015) proposes local and national governments, universities, civil society, and international cooperation actors as key players in the process of innovation creation and diffusion. In social innovation, the main actor can be an individual, an institution, or a group of individuals or institutions, as it usually includes the need for cooperation between actors. Therefore, each of the aforementioned actors (governments, universities, etc.) may be part of the main actor in the innovation or maybe support for its development and dissemination.

\footnotetext{
"Visión de Futuro" Año 19, Volumen No 26 N 1, Enero - Junio 2022 - Pág 149 - 168

URL de la Revista: http://visiondefuturo.fce.unam.edu.ar/index.php/visiondefuturo/index

URL del Documento: https://visiondefuturo.fce.unam.edu.ar/index.php/visiondefuturo/issue/view/22

ISSN 1668 - 8708 - Versión en Línea

E-mail: revistacientifica@fce.unam.edu.ar
} 
The innovation diffusion process is usually the result of interaction among these actors, with their interaction with the main innovation actor being particularly important. This process has two essential phases in social innovation. The first phase corresponds to diffusion in the territory. Social innovations are usually aimed at solving local problems associated with the territory, so their connection with the territory is essential. The direct beneficiaries are usually local agents. Consequently, the first step in diffusion is oriented to the beneficiaries to accept the innovation and assume it as their own. A second phase, which is more common with other innovations, is international diffusion and its extension to other territories. The ideas included in social innovation often have common aspects that serve to solve problems in other places where the innovation can be applied, either directly or by adapting it. In this sense, the dissemination of the innovation needs to be known in the territory and assumed by the potential beneficiaries of the innovation and then, or in parallel, made known to other territories for possible dissemination. Hence the importance of the geographical aspects associated with social innovation (Gierhake and Jardón, 2016).

In this diffusion process, the main barriers to social innovation arise precisely because of difficulties in the interaction between the different actors in the process. The diffusion model presented shows a series of categories that include the interaction of two or more actors in the diffusion process, indicating the performance of these actors in this interaction and the barriers that may arise as a result of this interaction. Local universities could play a key role in overcoming these difficulties.

\section{The role of local universities in social innovation}

The local knowledge existing in a territory presents two complementary aspects that, in many cases, are difficult to separate. On the one hand, there is the specific knowledge of the territory, a consequence of local traditions, usually tacit knowledge, which is difficult to formalize. On the other hand, there is scientific knowledge, the fruit of universal knowledge that is transmitted through educational centers essentially and reinforces local knowledge by interacting with it (Jardon and Gierhake, 2017). Local universities combine both types of knowledge, although local knowledge is usually explicit because only that which they can make explicit is transmitted. Social innovation relies, to a large extent, on local knowledge so the role of universities is evident in participating in the creation of social innovations.

The role of local universities is not usually limited to creation but also plays an important role in the dissemination of innovation. On the one hand, they must be able to provide the necessary training in the territory so that local agents can take up innovation and complete and apply it to the territory. In addition, they can be channels for disseminating innovation

\footnotetext{
"Visión de Futuro" Año 19, Volumen No 26 N 1, Enero - Junio 2022 - Pág 149 - 168

URL de la Revista: http://visiondefuturo.fce.unam.edu.ar/index.php/visiondefuturo/index

URL del Documento: https://visiondefuturo.fce.unam.edu.ar/index.php/visiondefuturo/issue/view/22

ISSN 1668 - 8708 - Versión en Línea

E-mail: revistacientifica@fce.unam.edu.ar
} 
among local agents, through territorial learning processes. On the other hand, it has a task in the dissemination of innovation to other universities, through publications, conferences, seminars, etc.... where they make known the theoretical aspects of innovation and its possibilities of extension to other territories (García-Flores and Martos, 2019; Sáez, 2017). This suggests that local universities can participate as one of the most important agents in its generation although the local university is not the main actor in social innovation. However, in any case, local universities usually have an essential task in its diffusion. The limitations existing in the local university are going to have a direct effect on social innovation by generating barriers that, at times, can impede the diffusion process.

The proposed model analyzes the possibility of interaction between the different components of the social innovation system. Specific local knowledge associated with the culture of the territory facilitates interaction between local actors but may hinder interaction with non-local, national, or international actors. Generic local knowledge facilitates interaction with all actors, highlighting the importance of the role of universities in the process.

Consequently, we propose two hypotheses to be analyzed in the $\mathrm{DMQ}$, both closely related to each other:

$\mathrm{H1}$ : Local universities play a preponderant role in the diffusion of social innovations in the territory.

$\mathrm{H} 2$ : The lack of collaboration of local universities in the diffusion process of a social innovation limits its diffusion.

\section{Methodology}

To analyze a geographical situation, it is necessary to combine theoretical information with territorial analysis. The theoretical framework has been elaborated after an exhaustive bibliographic review and the elaboration of the concepts that arise from the elements of local knowledge and social innovation.

This paper aimed to describe and explain the role of local universities in the diffusion of social innovation from a local knowledge approach, so a qualitative methodology seems more appropriate (Denzin and Lincoln, 2000). Consequently, different sources of empirical information have been used. On the one hand, the documentation of the municipality has been reviewed, both on the design of the strategic plan and the subsequent development of local knowledge in each of the organizational subunits. On the other hand, 40 semi-structured interviews were conducted with the main social actors of the process and outside observers, experts who made it possible to evaluate the causes for the realization of this process and to make criticisms of the defects associated with its operation or application, since semi-

\footnotetext{
"Visión de Futuro" Año 19, Volumen No 26 N 1, Enero - Junio 2022 - Pág 149 - 168

URL de la Revista: http://visiondefuturo.fce.unam.edu.ar/index.php/visiondefuturo/index

URL del Documento: https://visiondefuturo.fce.unam.edu.ar/index.php/visiondefuturo/issue/view/22

ISSN 1668 - 8708 - Versión en Línea

E-mail: revistacientifica@fce.unam.edu.ar
} 
structured interviews provide a valid instrument for combining scientific reliability with the possible subjective load of qualitative descriptions. Thirteen people from the DMQ were interviewed, covering the main hierarchical levels and the most important sectors for a territorial policy. The interview, following a multidisciplinary approach, covered a series of open questions on the management of the municipality, political organization, staff status and attitudes, finances, information system, working materials and infrastructures, process and activity efficiency, and external relations.

In some cases, more than one interview per person was conducted to evaluate and contrast the different opinions. In this way, the credibility of the interviewees was ensured, since the transfer of concepts, the dependence on local actors, and possibly external sources of confirmation of the results were taken into account (Lincoln and Guba, 1985).

In parallel, we have been observing in the field the explicit functioning of the municipality and its specific impact on the day-to-day life of the community of Quito and its surroundings, during 2014.

The information collected was cataloged and assigned to each of the basic theoretical concepts established. Subsequently, the relationships between the concepts were established using a qualitative analysis.

\section{Social innovation at MDQM}

The process of establishing social innovations in the DMQ has followed a top-down strategy, based on the development of a strategic plan including technological, economic, and social aspects (MDMQ, 2012b). The specific actions of that plan are examples of social innovations although the greatest innovations appear in the high level of integration between the sectoral components and the different partial projects (MDMQ, 2012c) and particular projects such as the digital agenda (MDMQ, 2012a). The diffusion process starts in the government team (innovative actor) is transmitted by the municipality (main diffusion actors) and then spread to other regions (adaptation actors) showing innovative characteristics, since it suggests an inverse process to the one established in the assumptions of the traditional model: these are innovations that are developed in developing countries that have the potential to move towards developed countries by presenting a conception based on their traditional local experience that is unknown in developed geographic science.

\section{Universities and local knowledge in the DMQ}

Part of the local knowledge is manifested in its contact with the different universities in the territory. Universities are theoretically a source of innovation (Lara et al., 2020). The

\footnotetext{
“Visión de Futuro" Año 19, Volumen No 26 N 1, Enero - Junio 2022 - Pág 149 - 168

URL de la Revista: http://visiondefuturo.fce.unam.edu.ar/index.php/visiondefuturo/index

URL del Documento: https://visiondefuturo.fce.unam.edu.ar/index.php/visiondefuturo/issue/view/22

ISSN 1668 - 8708 - Versión en Línea

E-mail: revistacientifica@fce.unam.edu.ar
} 
Metropolitan District concentrates the best universities in the country and, in particular, the only two with doctoral degrees (FLACSO, Universidad Andina Simón Bolívar) and the oldest public university in the country (Universidad Central). It also has several recognized private universities (Catholic, San Francisco). Traditionally, Quito's academic institutions have been considered of a lower level than those of other nearby territories, such as Lima or Bogotá. As a consequence, the Mayor decidedly bet on the City Institute as an applied science entity to support municipal policies (think tank), to develop the plan, and enhance the excellence of the administrative structure (Gierhake and Jardón, 2016). Therefore, in practice, universities were not a source of innovation in the case of the DMQ.

The manifestations of local knowledge outside the universities appear in the shared perception between municipal government and citizens and are reflected in the participatory municipal development plans, in the interaction of local administrations with citizens, and the promotion of public-private actions. It is also shown in a certain environmental culture since Quito was one of the first cities to introduce environmental policies in the Municipality (Mayor's Office of Jamil Mahuad), which have been maintained (Barrera, 2014).

Previous works have studied particular expressions of social innovation and their relationship with different groups of factors key to the birth of this process of social innovation, a holistic program of modernization of the Municipality's administration, and the planning and implementation of the different components of this program. In particular, the importance of local knowledge (Gierhake and Jardon, 2017); creative territories factors (Gierhake and Fernandez-Jardon, 2017), and metropolitan networks (Jardon and Gierhake, 2018) have been highlighted. However, the different effects of territory-specific local knowledge and more generic local knowledge transmitted by universities were not analyzed in detail. It is this connection that made it possible to move from the static view of the existence of local knowledge towards a dynamic view of the diffusion of this knowledge and associated innovation. This is the aspect on which this study focuses. Table 1 summarizes the results of previous analyses in the case of the DMQ, from a static approach. In the following lines, the dynamic process associated with the diffusion of innovation is analyzed more specifically.

\footnotetext{
"Visión de Futuro" Año 19, Volumen No 26 N 1, Enero - Junio 2022 - Pág 149 - 168 URL de la Revista: http://visiondefuturo.fce.unam.edu.ar/index.php/visiondefuturo/index

URL del Documento: https://visiondefuturo.fce.unam.edu.ar/index.php/visiondefuturo/issue/view/22

ISSN 1668 - 8708 - Versión en Línea

E-mail: revistacientifica@fce.unam.edu.ar
} 
Table 1: Indicators of social innovation in DMQ

\section{Indicators related to creative territory factors (examples):}

The infrastructure of Universities/Research Centers, Broad institutional social platform for the presentation of cultural expressions, Magnetic impact by new ideas and general concepts, Cultural exchange going beyond the layers of society. Demand for public values by the Civil Society. Support physical spaces that facilitate interaction, Local policy culture (intelligent Quito).

Metropolitan Network Indicators (examples):

Develop management mechanisms at the political-administrative level. Build community networks to face the challenges of globalization. Obtain new knowledge through international cooperation, Structure new knowledge and avoid information isolation, Take advantage of the multiplier impact of metropolitan areas, High centrality in the institutional perspective.

Intellectual Capital / Local Knowledge Indicators (examples):

a) human: training of professionals, integration and leadership skills, coordination, entrepreneurial skills

b) structural: monitoring mechanisms, activities to encourage dialogue, recovering the centrality of human beings, technological knowledge

c) relational: extensive international relations, communication/participation

Source: Own elaboration

The elements detected in the static analysis point to aspects that have helped to create social innovations and that possibly also act on the innovation diffusion process, suggesting possible barriers to this process.

Based on this previous papers and to understand the advances and barriers in the first stage of the diffusion of this innovation, a schematic map of the DMQ is presented (see Figure 1), showing the social innovation that was carried out. The figure presents two levels of analysis as previously mentioned. The first level shows a more static sectoral approach. At the center are the main factors that determine the birth of innovation: intellectual capital and territory. The combination of these two elements gives rise to creative territories and the local knowledge of the population, elements that are also at the birth of innovation.

Complementarily, the metropolitan networks in which the DMQ participated appear, which have served as a knowledge base for the creation of innovation and as a key element in the international diffusion of innovation. Around the center of the figure, the main actors are described, with the role they played in innovation, introducing the dynamic analysis with the relationships established to maintain and disseminate innovation in the territory. The role of the local government, as the main actor, and of the universities as the main complementary institutions to create, systematize and disseminate professional knowledge associated with innovation is especially highlighted.

\footnotetext{
"Visión de Futuro" Año 19, Volumen No 26 No 1, Enero - Junio 2022 - Pág 149 - 168 URL de la Revista: http://visiondefuturo.fce.unam.edu.ar/index.php/visiondefuturo/index

URL del Documento: https://visiondefuturo.fce.unam.edu.ar/index.php/visiondefuturo/issue/view/22 
The holistic territorial approach to the process of innovation diffusion in the territory introduces the analysis of territorial impacts with the geography of the innovation approach. This dynamic vision makes it possible to introduce the barriers that arise in the interaction of the actors among themselves and with the territory when diffusing this process. The introduction of these barriers suggests possible policy actions associated with the improvement and overcoming of these barriers.

As a result of the analysis in Figure 1, it is suggested that institutional actors are essential in the process of social innovation. In particular, it is possible to observe the role that local universities in the territory played or should play in this process. At different stages of the process, the universities combined with other actors or institutions formed institutional figures, which can be grouped by shared characteristics, which were denominated in the work as an agglomeration of actors. Each of these agglomerations shows certain characteristics (which will be called a category) which will be the basis of the possible barriers to the diffusion of social innovation due to non-shared or non-existent knowledge. In particular, the following categories stand out:

\footnotetext{
"Visión de Futuro" Año 19, Volumen No 26 N 1, Enero - Junio 2022 - Pág 149 - 168

URL de la Revista: http://visiondefuturo.fce.unam.edu.ar/index.php/visiondefuturo/index

URL del Documento: https://visiondefuturo.fce.unam.edu.ar/index.php/visiondefuturo/issue/view/22

ISSN 1668 - 8708 - Versión en Línea

E-mail: revistacientifica@fce.unam.edu.ar
} 


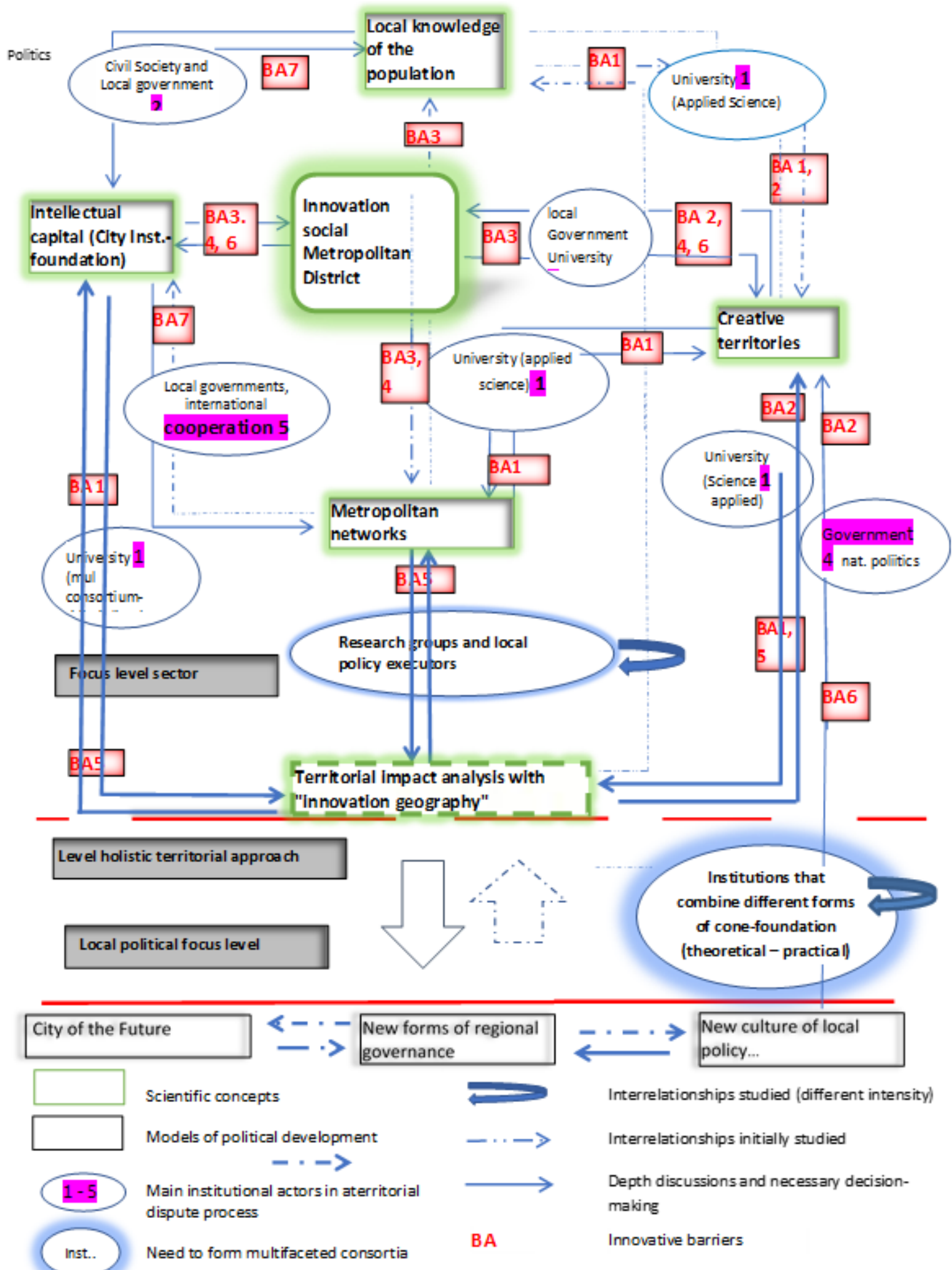

Figure 1: Barriers to Social Innovation Source: Own elaboration

Category 1: Coordination between the University and Civil Society, working with applied science: Applied science as a scientific orientation is practically unknown in Ecuador, although

\footnotetext{
"Visión de Futuro" Año 19, Volumen $N^{0} 26$ No 1, Enero - Junio 2022 - Pág 149 - 168

URL de la Revista: http://visiondefuturo.fce.unam.edu.ar/index.php/visiondefuturo/index

URL del Documento: https://visiondefuturo.fce.unam.edu.ar/index.php/visiondefuturo/issue/view/22

ISSN 1668 - 8708 - Versión en Línea

E-mail: revistacientifica@fce.unam.edu.ar
} 
the University in Ecuador has three functions: teaching, research, and service to society. In particular, this limitation of knowledge also refers to Geography. There is only one faculty in the country, and it has a clear orientation towards physical geography. The topic related to local knowledge is interpreted as a rural aspect, related to ancestral knowledge of indigenous people, especially in health and environmental issues. Consequently, there is hardly any regional research, understood as research on the sustainable development of the DMQ. In response to this need, the role of the Institute of the City was strengthened, but in disconnection with local universities.

Category 2: Civil Society in cooperation with Local Government: MDMQ had managed to hire several people from civil society, with deep experience in other sectors of society or with experience working in other countries. This served to leverage local knowledge (from professionals working in the upper hierarchies of the MDMQ). However, economic interest groups (e.g., motorists, store owners) did not accept the innovation process, claiming to maintain previous privileges (e.g., free car parking in public space or refusing to build boulevards with ample space for pedestrians), limiting collaboration with civil society.

Category 3: The relationship between Universities and Local Government: There were several attempts to install platforms and dialogue, but the universities did not respond. The territorial perspective of the MDMQ was criticized in the universities, without knowing the contents of the MDMQ program sufficiently, nor its possible international scope in the already visible territorial policies.

Category 4: Interaction between the Local Government and the National Government: The fact that the authorities of both governments were from the same party and shared the same objectives (Development Plan, Land Management), presented favorable expectations. In addition, there were advantages due to the geographic proximity of both headquarters (for example, the offices of both institutions were located on two sides of the Main Square). This fact facilitated the implementation of projects but did not support the new culture of local policy, a fundamental line of the MDMQ, since the policy of the National Government was perceived as very centralist by the MDMQ. In terms of international networks as a dissemination mechanism, the MDMQ was better positioned, facilitating dissemination at the international level, an aspect in which the central government did not intervene.

Category 5: The connection between local governments and international cooperation: The MDMQ was in a good position to prioritize international cooperation since there was an increase in the supply of development workers with interest in the municipality, (for example, the German Cooperation collaborated in the territorial planning part). In addition, there was a lot of cooperation at the level of international municipal bodies (Jardon and Gierhake, 2018). 
The MDMQ participated in many networks and had even assumed responsibilities in some of them (vice-presidency ...). The DMQ was in a good position to facilitate the flow of information (diffusion of innovative ideas, both to create innovations and to disseminate them internationally) (Jardon and Gierhake, 2018), On the other hand, the decision to hold the HABITAT 3 conference in Quito could be a sign of the successful institutional positioning of the municipality at the international level.

As a consequence of these observations on actors, their knowledge, and respective knowledge management, the following barriers (BA) associated with the role of universities, either directly or indirectly, can be formulated:

(BA1) A first aspect that slowed down the diffusion of innovations was the connection between the university and the different innovation actors. Universities were potential actors to promote the diffusion of innovative ideas to a part of society, but they maintained traditional views that slowed down the diffusion of innovation. For example, the national Prometheus program, designed to modernize universities and introduce them into international discussion circles, was possibly a line of diffusion. However, it was not possible to create impacts in the area of innovation policies and territory, among other aspects, because of the poor connection of universities with society and with the innovation process.

(BA2) A second aspect refers to the use of different concepts or the lack of concepts related to social innovation existing in the local university since only administrative territories (socio-administrative statistics) and natural territories (watersheds, etc.) are known. The concepts of functional territories (defined by certain factors that induce other economic or social processes) and virtual territories (defined by potential problems shared by other similar institutions such as, for example, other municipalities, not necessarily sharing the same boundaries) were not known by local university institutions. Therefore, it was not possible to adequately analyze those territorial movements that showed certain socio-economic characteristics.

(BA3) Local universities present little culture of multidisciplinary research and territorial processes related to the barriers mentioned above, and above all, there is hardly any particular orientation towards social-economic issues. With the Barrera administration, a training program was introduced through the City Institute to strengthen applied science oriented towards the needs of the Municipality, but it did not reach the scientific heights that the universities could have developed.

(BA4) Civil society and local government did not share the political-cultural concepts: The Barrera administration introduced several new concepts related to the reorganization of the administrative structure, improvements in information flow, and new local policy culture.

\footnotetext{
“Visión de Futuro" Año 19, Volumen No 26 N 1, Enero - Junio 2022 - Pág 149 - 168 URL de la Revista: http://visiondefuturo.fce.unam.edu.ar/index.php/visiondefuturo/index

URL del Documento: https://visiondefuturo.fce.unam.edu.ar/index.php/visiondefuturo/issue/view/22

ISSN 1668 - 8708 - Versión en Línea

E-mail: revistacientifica@fce.unam.edu.ar
} 
However, the lower hierarchies of the administration did not adequately integrate these concepts, so they did not identify with this process, did not support it, and as a consequence, many of the ideas did not reach an important part of the population. In addition, certain projects affected the interests of economic and political interest groups. For example, the large boulevards for pedestrians instead of free parking for cars, or the network of bicycle lanes, or the permanent premises with better sanitary conditions for street vendors; or the implementation of fines for bad parking, etc. ... All of which created a wave of protests, which slowed down the diffusion of innovation. The lack of civic culture, to which the university could give more support, was at the root of this limitation.

(BA5) Lack of impact monitoring by the local government. The development of innovation in the DMQ only presented progress monitoring. This prevented tracking the performance of complex activities, activities that include new perceptions, and above all the change of perceptions, fundamental aspects in social innovation processes as complex as the case of the MDMQ. This analysis required broadly multidisciplinary training, little known in Ecuador, possibly because of the aspects previously commented concerning universities. As a result, information on the processes was not available. In fact, in some aspects, they progressed better than expected, for example, international municipal contacts and the dissemination of knowledge in these networks, but in others, such as the connection with citizens, they fell short and there was no time to readjust the process. The main actor in the innovation process (MDMQ) did not have time to evaluate the scope of the project, perhaps because he had not thought it was such a broad innovative project. The lack of adequate contacts with universities, which could be in a position to measure and compare such progress, limited adequate communication about it, and in a second step, produced limitations in the knowledge about the progress in metropolitan innovative policies at the local population level.

(BA6) The main actor in the innovation process (MDMQ) did not have time to evaluate the scope of the project in general, probably because it had not thought of it as a broad innovative project. Although it identified the lack of adequate contacts with an academy in a position to measure and compare progress and tried to alleviate this with the strengthening of the City Institute, this effort was not sufficient. Limited knowledge in a large part of civil society and a reluctance to change innovative metropolitan policies slowed down the process of innovation diffusion. Short government times coupled with the pressure to implement something visible are everyday problems in Latin America. In this scenario, impact monitoring would represent an important instrument, for example, to measure and communicate progress. The fact that this concept of impact monitoring did not exist, reflects an important barrier

\footnotetext{
"Visión de Futuro" Año 19, Volumen No 26 N 1, Enero - Junio 2022 - Pág 149 - 168 URL de la Revista: http://visiondefuturo.fce.unam.edu.ar/index.php/visiondefuturo/index

URL del Documento: https://visiondefuturo.fce.unam.edu.ar/index.php/visiondefuturo/issue/view/22 
(BA7) As a consequence of the above, it was not possible to convince a large part of civil society of the broad advantages of social innovation in the MDMQ. The project's development and implementation time was short, four years since the mayor was not reelected. The public relations work was deficient, with many changes in the public relations department, and the informal movements were underestimated, with the belief that the good results would be convincing. As a consequence, it could be observed that the knowledge of progress was limited in the local society, mixed with ambivalent idiosyncrasies existing in the Quiteño culture, where a certain cultural and social innovation and professional seriousness is combined with the informal aspects of Latin American culture.

\section{CONCLUSION}

The paper analyzes the role of universities in the process of social innovation in the MDMQ from a local knowledge approach, showing that the original concept of geographic processes of innovation and its connection with territorial development from a local knowledge approach serves as a basis for adapting it to different environments and analyzing complex processes of social innovation. In combination with the concept of local knowledge, the geography of innovation approach achieves an added value, suggesting conditioning factors of the innovation diffusion process within a creative environment.

Social innovation is manifested in the fact that the Augusto Barrera administration (MDMQ 2009-2014) has implemented a holistic project of administrative modernization and modernization of the territorial structures of the Metropolitan District (this includes all aspects of sustainable development). This modernization project is reflected in the Metropolitan Development Plan - Quito 2021-2022, and a series of partial/sectorial documents, which were elaborated based on this Development Plan and has had all the characteristics of social innovation; in the design of a work, agenda to constitute a digital city based on a collaborative model and in the dynamic characteristics of this transformation, showing specific elements of the geographical processes of innovation, such as innovative actors, diffusion actors, and adaptation actors. This process has shown originality since it starts from developing countries and presents a high potential to reach developed countries.

The structure of the different institutional actors, their location about scientific concepts that explain the progress of an innovation process, and the barriers identified to allow for a series of conclusions:

Firstly, there are potential actors to promote the dissemination of innovative ideas to a part of society. Among them, it is worth mentioning the universities, as an actor with two important characteristics: on the one hand, certain sustainability, independent of political

\footnotetext{
"Visión de Futuro" Año 19, Volumen No 26 N 1, Enero - Junio 2022 - Pág 149 - 168

URL de la Revista: http://visiondefuturo.fce.unam.edu.ar/index.php/visiondefuturo/index

URL del Documento: https://visiondefuturo.fce.unam.edu.ar/index.php/visiondefuturo/issue/view/22

ISSN 1668 - 8708 - Versión en Línea

E-mail: revistacientifica@fce.unam.edu.ar
} 
changes; on the other hand, a potential catalyst of novelties, because they concentrate a higher education population, are more open to changes than the average and theoretically have contacts with foreign countries. Within the ambitious national development program (Buen Vivir), an important role was given to the modernization of universities (Programa Prometeo, Ciudad Universitaria Yachay), but the universities maintained traditional views. Possible reasons could be the existence of a certain time lag to implement new administrative structures, a limitation of scientific concepts and measures to transform these structures into university activities; an unclear perception of an overload of novel activities in society; and a negative perception of measures decided by the National Government that was expressed at the local level in criticisms about the Municipality.

An ambitious social innovation such as the one carried out in MDQM, aimed at processes that allowed to take advantage of knowledge, plan, monitor, and introduce learned aspects in the process, required a constellation of a consortium of actors, especially the local government and the academy. The academy represents a highly diverse institutional figure, between private and public universities, and between different faculties of the same university. This diversity was essential for creating and disseminating innovation. It would have been essential to promoting innovation after its introduction and first diffusion experiences. However, the organization of a favorable institutional structure could not be developed into a functioning structure, co-directing this diffusion process. Many different aspects converge in the categories of actors that determine their position to accept or reject an innovation. If a stakeholder is misinformed (or rejects innovations to maintain past structures), frictional losses occur in communication and the sharing of the necessary knowledge. Within the concept of innovation and especially its diffusion, this lack of collaboration between the key actors of the process generated a non-visible barrier (without having the arguments to move to a rejection). An example of this aspect is shown in the fact that the Municipality identified the limited knowledge it had to analyze territorial processes, and made efforts to overcome this limitation by creating the Institute of the City, but this institution was not enough to solve the problem of diffusion in the territory.

Secondly, there are agglomerations of actors with particular and conflicting objectives in certain parts of the dissemination process, pointing to two complementary aspects. On the one hand, the barriers present are not surprising, since this is a broad program of social innovation and it is logical that there should be obstacles to this process. On the other hand, it shows that the processes associated with social innovation are different from economic innovation processes, although the actors act with similar rationalities.

\footnotetext{
“Visión de Futuro" Año 19, Volumen No 26 N 1, Enero - Junio 2022 - Pág 149 - 168 URL de la Revista: http://visiondefuturo.fce.unam.edu.ar/index.php/visiondefuturo/index

URL del Documento: https://visiondefuturo.fce.unam.edu.ar/index.php/visiondefuturo/issue/view/22

ISSN 1668 - 8708 - Versión en Línea

E-mail: revistacientifica@fce.unam.edu.ar
} 
Third, the paper shows that there was extensive and far-reaching local knowledge in the $D M Q$ to initiate a process of social innovation in the local government and its jurisdiction. Based on the comments from all the interviews, the mayor could gather and structure this knowledge within his administration. In the terminology of territorial innovation processes, this constellation of actors and situations allowed the introduction and initial diffusion of innovation, concentrating on the upper and middle levels of the Municipality, and probably reached the same social layers of civil society and international institutions. In particular, it is striking that the advances at the international level, valued in contexts other than Ecuador's, have not been able to translate into positive impacts for the national diffusion of innovation. Possible explanations that would require further research into the processes of acceptance or rejection of social innovations, especially those with political implications, and how they overcome external factors, as has happened in the case of growing criticism of the National Government in Ecuador.

A fourth aspect suggests that, at the level of a process evaluation, from a dynamic viewpoint, the original process model of innovation has been extended to a view that includes dynamic aspects (diffusion), highlighting possible particularities in the movement of social innovation in a territory, including its actors and potential barriers. This processing fits well into the main vision of applied science, since it presents some results, discusses them with potential users, introduces new concepts, and reanalyzes empirical data. On the theoretical level, it has been shown how two sciences can contribute to the interpretation of innovation diffusion processes. Points of contact between the two sciences (economics and economic social geography) have been identified, reaching a more aggregated level of explanation.

Finally, it was possible to show that there is a complementarity between knowledge of the European area, with advances in theory and construction of scientific models, with certain advantages in the accumulation of particular experiences, at the level of execution of activities in Latin America. In this way, the limitations that the theoretical concepts present at the empirical level are complemented, especially looking at regions outside Europe and Latin America, and the existing lack of a deeper analysis of their positive impacts or limitations found in some of these territories.

The paper has some limitations that should be considered when extending the results. On the one hand, the analysis is carried out with qualitative indicators, although they could represent the basis for developing and testing these results with quantitative indicators at a later stage. On the other hand, it has combined the approach of two sciences, but, to advance the analysis, it would be convenient to introduce other sciences with their respective research concepts. In the graph we suggest some aspects associated with political science and related

\footnotetext{
“Visión de Futuro" Año 19, Volumen No 26 N 1, Enero - Junio 2022 - Pág 149 - 168 URL de la Revista: http://visiondefuturo.fce.unam.edu.ar/index.php/visiondefuturo/index

URL del Documento: https://visiondefuturo.fce.unam.edu.ar/index.php/visiondefuturo/issue/view/22

ISSN 1668 - 8708 - Versión en Línea

E-mail: revistacientifica@fce.unam.edu.ar
} 
to local governance that could be taken as a starting point to specify possibilities of using the results of social innovation and local governments at the level of local policies, leaving open new lines of research.

\section{REFERENCES}

Please refer to articles in Spanish Bibliography.

\section{BIBLIOGRAPHICAL ABSTRACT}

Please refer to articles Spanish Biographical abstract. 